\title{
Antioxidant Activity of Hydro-Acetonic, Hydro-Methanolic and Aqueous Leaf and Bark Extracts of Sclerocaria birrea (A. Rich.) Hochst
}

\author{
Lahat Niang1,2, Seid Ali Mahamat' ${ }^{3}$, Nicolas Cyrille Ayessou ${ }^{1,2 *}$, Mady Cisse ${ }^{1,2}$, Codou Mar Diop ${ }^{1,2}$ \\ ${ }^{1}$ Laboratory of Electrochemistry and Membrane Processes (LEPM), ESP-UCAD, Dakar, Sénégal \\ ${ }^{2}$ Center for Studies on Food Safety and Functional Molecules (CESAM-RESCIF), ESP-UCAD, Dakar, Sénégal \\ ${ }^{3}$ Adam Barka University, Abeche, Tchad \\ Email: *nicolas.ayessou@ucad.edu.sn
}

How to cite this paper: Niang, L., Mahamat, S.A., Ayessou, N.C., Cisse, M. and Diop, C.M. (2021) Antioxidant Activity of Hydro-Acetonic, Hydro-Methanolic and Aqueous Leaf and Bark Extracts of Sclerocaria birrea (A. Rich.) Hochst. Food and Nutrition Sciences, 12, 429-438.

https://doi.org/10.4236/fns.2021.125033

Received: March 14, 2021

Accepted: May 8, 2021

Published: May 11, 2021

Copyright $\odot 2021$ by author(s) and Scientific Research Publishing Inc. This work is licensed under the Creative Commons Attribution International License (CC BY 4.0).

http://creativecommons.org/licenses/by/4.0/

\section{(c) (i) Open Access}

\begin{abstract}
Bioactive compounds in plants are associated with the reduction of chronic diseases. The free radical scavenging activity of different extracts of a medicinal plant, Sclerocarya birrea, has been investigated using the DPPH test, ABTS test and FRAP. Three extracts were prepared from the leaves and bark: hydro-methanolic, hydro-acetonic and aqueous. Phytochemical screening was carried out the standard methods followed by the determination of the polyphenol by Folin-Ciocalteu method. The analysis of variance (ANOVA) with the STATISTICA 7.1 and statistical significance was set at $\mathrm{p}<0.05$. Evolution of percent inhibition (PI) as well as the $\mathrm{IC}_{50}$ of the extracts was obtained using the Origin Pro 8.5 software and Microsoft Excel. The results show that the bark extracts are about twice as rich in polyphenols as the leaves. With DPPH at $1.25 \mathrm{mg} / \mathrm{mL}$, the bark has a PI of $91.04 \% \pm 0.001 \%$ while leaves, reach $99.80 \% \pm 0.021 \%$. As for the ABTS test, the bark extract reached its maximum activity at $1.25 \mathrm{mg} / \mathrm{mL}$ with a PI of $99.80 \% \pm 0.003 \%$ while leaves extract greater value of PI is $99.75 \pm 0.003$ at $2.5 \mathrm{mg} / \mathrm{mL}$. With FRAP test at $1.25 \mathrm{mg} / \mathrm{mL}$, the bark has a PI of $79.29 \% \pm 0.005 \%$ while leaves, reach $80.33 \% \pm 0.001 \%$. The $\mathrm{IC}_{50}$ of the bark and leaf extracts on the smallest DPPH are $0.156 \pm 0.001 \mathrm{mg} / \mathrm{mL}$ in hydro-methanol, $0.301 \pm 0.00 \mathrm{mg} / \mathrm{mL}$ in hydro-acetone and $0.407 \pm 0.00 \mathrm{mg} / \mathrm{mL}$ in aqueous extract. With ABTS test, the best $\mathrm{IC}_{50}$ are obtained with hydro-acetone extracts with value of $0.247 \pm$ $0.001 \mathrm{mg} / \mathrm{mL}$ for bark and $0.248 \pm 0.0005 \mathrm{mg} / \mathrm{mL}$ for leaves while in hydro-methanolic and aqueous extracts the best $\mathrm{IC}_{50}$ are respectively $0.255 \pm$ $0.00 \mathrm{mg} / \mathrm{mL}$ and $0.463 \pm 0.00 \mathrm{mg} / \mathrm{mL}$. Using ascorbic acid as our standard, the PI was $94.86 \% \pm 0.008 \%$ with an $\mathrm{IC}_{50}$ of $0.213 \pm 0.00 \mathrm{mg} / \mathrm{mL}$. According to these results, the reducing power of the bark is slightly higher than that of
\end{abstract}


the leaves. We can say that the bark has better activity than the leaves and the alcoholic extracts have given better results than the aqueous extract.

\section{Keywords}

Sclerocarya birrea, Antioxidant Activity, DPPH, ABTS, Total Phenolic

\section{Introduction}

The use of plants (fruits, leaves, etc.) by traditional medicine to fight against diseases linked to free radicals such as asthma, cancer and diabetes is well known [1]. Some vegetable phytochemicals (glucosinolates, thiosulfates, polyphenols, bioactive peptides, etc.) have positive effects on health [2]. They are strong antioxidants and they reduce the risk of chronic diseases by protecting against free radical damage, by modifying metabolic activation and detoxification of carcinogens [3]. Among all the chemical constituents of plants, phenolic compounds occupy an important place with several properties sought by man in particular in the analytical and biotechnological fields. Some plants such as green and black tea have strong antioxidant activity, which is due to their high polyphenol content [4]. Free radicals contribute to the occurrence of serious diseases such as cancer, diabetes and cardiovascular diseases [5]. Other phytochemical constituents (terpenoids, carotenoids, vitamins $\mathrm{C}$ and $\mathrm{E}$ ) are also known for their antioxidant capacity [6]. The high cost of drugs, the inaccessibility of health care and the effectiveness and availability of medicinal plants are pushing populations towards herbal medicine. Many diseases including diabetes are treated satisfactorily and affordably with medicinal plants due to their active substances. In Senegal, leaves and bark of Sclerocarya birrea are also used for certain diseases, such as diabetes by population and the plant is very accessible [7] [8] [9]. According to that, investigations are conducted to assess their antioxidant activity through three methods and three extracts solutions like aqueous, hydro-methanolic and acetonic. This has been achieved in order to get complete information and to project on possible applications.

\section{Materials and Methods}

\subsection{Collection and Identification of Plant}

Leaves and bark of Sclerocarya birrea were collected in May 2019, the flowering period, at Diourbel region (Senegal). The plant was identified and authenticated in botany-biodiversité laboratory, plant biology department of Cheikh Anta Diop University in Dakar. Plant leaves and bark were washed with distilled water and air-dried at room temperature in the laboratory. Dried leaves and bark were ground to a fine powder using an electric grinder (Kenwood, France). The sifted powder with $1 \mathrm{~mm}$ mesh is stored at $4^{\circ} \mathrm{C}$ in airtight jars. Thus, the powders are then subjected to two extraction methods: by infusion and by Soxhlet. 


\subsubsection{Infusion}

Infusions are made in triplicate with boiling distilled water. The ratios are $10 \mathrm{~g}$ $( \pm 0.01 \mathrm{~g})$ of powder in $100 \mathrm{~mL}$ of solvent. After cooling, the infused products are filtered under vacuum and then stored in a sterile glass bottle tightly closed at $4^{\circ} \mathrm{C}$.

\subsubsection{Extraction under Reflux}

The extraction is carried out with methanol (70\% v/v), (99.98\%, Scharlau Chemie SA, SPAIN) and acetone (70\% v/v), (99.5\%, Scharlab SL, SPAIN) on an outlet of $10 \mathrm{~g}( \pm 0.01 \mathrm{~g})$ of vegetable powder brought into contact with the solvent for two hours. After cooling, the mixture is separated using a centrifuge (Hittich, Universal $16 \mathrm{~A}$, France) at $3000 \mathrm{rpm}$ for 10 minutes then vacuum filtered on Wattman No.1 paper in order to obtain on the one hand the cake and on the other hand the filtrate consisting of the extract and the solvent. In the extracts, traces of solvent are removed using a rotary evaporator (IKA ${ }^{\circ}, \mathrm{RV} 10-$ German).

\subsection{Qualitative Phytochemical Screening}

Standard phytochemical analyses were carried out to test for the presence of the phytoconstituents in the extracts. Chemical tests were carried out on hydro-acetone, hydro-methanolic and aqueous extracts using standard methods for the detection of tannins (Stiasny test followed by ferric chloride test), flavonoids (Shibata's test) [10], steroids and triterpenoids (Liebermann-Buchard test) [11] alkaloïds (Valser-Mayer and Dragendorff's reagents tests), saponins (foaming index) [12].

\subsection{Determination of Total Phenolic Content}

Total phenolic content (TPC) of the sample was estimated by the Folin-Ciocalteu method as described elsewhere slightly modified [13]. In brief, $50 \mu \mathrm{L}$ of sample diluted to $450 \mu \mathrm{L}$ with distilled water and standard was added to $2500 \mu \mathrm{L}$ of ten times diluted Folin-Ciocalteu reagent. Then, after adding $2.5 \mathrm{~mL}$ of $0.75 \%$ sodium carbonate, (all from Sigma-Aldrich Chemie, Germany), the mixtures were vortexed and incubated at $50^{\circ} \mathrm{C}$ in a water bath for 15 minutes. The samples prepared above were kept the samples pin the dark at room temperature for 30 minutes. Thereafter, the absorbance of each sample was read at $760 \mathrm{~nm}$ against the blank. Gallic acid was used for the calibration of a standard curve. Gallic acid dilution series at different concentration $(0.02-0.04-0.06-0.08-0.1-0.12$ $0.14 \mathrm{mg} / \mathrm{mL}$ ) was used for calibration curve in the same way as the extracts. TPC was determined as gallic acid equivalents (GAE) and values were expressed as mg GAE/g dry matter (DM) of plant extract.

\subsection{Evaluation of Antioxidant Activity}

\subsubsection{DPPH Radical Scavenging Assay}

The antioxidant activity was evaluated with DPPH (2, 2-diphenyl-1-picrylhydrazyl, Sigma, chemical company, USA) by making some modifications to the method 
[14]. The method is based on the ability of an extract to donate a singular electron to the radical free DPPH of dark purple color to stabilize it in DPPH of yellow-green color. Thus, $100 \mu \mathrm{L}$ of extracts were introduced into a test tube containing $1300 \mu \mathrm{L}$ of DPPH (0.004\% prepared in methanol). The negative control is prepared by mixing $100 \mu \mathrm{L}$ of methanol with $1300 \mu \mathrm{L}$ of the methanolic solution of DPPH. The positive control is represented by a solution of a standard antioxidant, ascorbic acid (AnalaR NORMAPUR, Leuven, Belgium) tested at different concentrations $(0.039,0.078,0.156,0.313,0.625,1.2$, and $2.5 \mathrm{mg} / \mathrm{mL})$ the absorbance of which was measured under the same conditions as the samples and for each concentration. The samples were kept in the dark for 15 minutes at room temperature and absorbance was measured at $517 \mathrm{~nm}$ on a UV/visible light spectrophotometer (Spectronic Genesys 8, Rochester, USA). All determinations were carried out in triplicate. Radical scavenging activity was calculated by the following formula:

$$
I(\%)=100\left(\frac{A_{c o}-A_{e x}}{A_{c o}}\right)
$$

$I(\%)$ : Antioxidant activity as a percentage of inhibition of DPPH.

$A_{c o}$ : absorbance of blank sample ( $\left.\mathrm{t}=0 \mathrm{~min}\right)$;

$A_{E x} \dot{x}$ absorbance of tested extract solution $(\mathrm{t}=15 \mathrm{~min})$.

\subsubsection{ABTS Radical Cation Decolourisation Assay}

The anti-free radical activity was also evaluated by ABTS, 2,2-azinobis (3 ethylbenzothiazoline-6-sul-fonic acid) diammonium salt (Sigma-Aldrich Chemie, Steinheim, Germany) radical cation decolourisation test using spectrophotometric method [15]. ABTS was dissolved in distilled water to a concentration of $7 \mathrm{nM}$. The solution of the ABTS cation radical was obtained by incubating for 12 to 16 $\mathrm{h}$ in the dark and at room temperature a mixture of equal volumes of the stock ABTS solution with a solution of potassium persulfate (99\%, Scharlab SL, Spain) at $2.45 \mathrm{nM}$. ABTS cation solution was diluted with ethanol to an absorbance of $0.700 \pm 0.02$ at $734 \mathrm{~nm}$ before use. Then $1500 \mu \mathrm{l}$ of ABTS cation solution were mixed with $50 \mu \mathrm{l}$ of extract solution or reference (ascorbic acid) at different concentrations (same of the DPPH). The samples were kept in the dark for 15 minutes at room temperature and absorption was measured at $734 \mathrm{~nm}$ on a spectrophotometer. All determinations were carried out in triplicate. Results were expressed as percentage inhibition (PI) as previously described for DPPH test.

\subsubsection{Ferric Reducing Antioxidant Power assay (FRAP)}

The ferric reducing power was determined according to the described method [16].An aliquot of $0.4 \mathrm{~mL}$ of each sample at different concentrations $(0.039$, $0.078,0.156,0.313,0.625,1.2$ and $2.5 \mathrm{mg} / \mathrm{mL}$ ) is mixed with $1 \mathrm{~mL}$ of phosphate buffered saline (0.2 M; pH 6.6; Scharlab S.L, Spain) and $1 \mathrm{~mL}$ of $1 \%$ potassium ferricyanide $\left(\mathrm{K}_{3} \mathrm{Fe}(\mathrm{CN})_{6} ; 99.8 \%\right.$, AppliChem Gmbh, Germany). The mixture was incubated at $50^{\circ} \mathrm{C}$ for $30 \mathrm{~min}$ and $1 \mathrm{~mL}$ of $10 \%$ trichloroacetic acid $(99.5 \%$, Scharlab S.L, Spain) was added. After shaked for 5 minutes, $1 \mathrm{~mL}$ of the mixture 
was mixed with $0.2 \mathrm{~mL}$ of ferric chloride $(0.1 \%)$ and left to stand in the dark for 30 minutes. Absorbance was measured at $700 \mathrm{~nm}$; ascorbic acid was used as positive control. All determinations were carried out in triplicate.

The antioxidant activity linked to the ferric reducing power of the extracts is expressed in Reducing Power (RP) using the following formula:

$$
\operatorname{RP}(\%)=100\left(\frac{A_{E x}-A_{C o}}{A_{E x}}\right)
$$

$A_{E x}:$ absorbance of tested extract solution

$A_{C o}$ : absorbance of blank sample $(\mathrm{t}=0 \mathrm{~min})$.

\subsection{Statistical Analysis}

The analytical results obtained from tree trials were processed using analysis of variance (ANOVA) with STATISTICA 7.1. The results were considered statistically significant if $\mathrm{P}$ value was $<0.05$. The $\mathrm{IC}_{50}$ was obtained using the Origine Pro 8.5 software and Microsoft Excel.

\section{Results and Discussion}

\subsection{Phytochemical Screening}

Phytochemical testing of plant materials is used to identify secondary metabolite compound. Such compounds while not a requirement for normal body function, are often found on evaluation to have positive effects on human health and can play an active role in prevention and treatment of disease [17]. Sclerocarya birrea extracts revealed a significant presence of phenols, tannins, flavonoids, saponins and traces of alkaloids and steroids. In contrast, there is an absence of saponosides in the barks of $S$. birrea. The presence of these phytochemical compounds in the plant materials suggests the potential medicinal value of their extracts in the prevention and/or cure of specific diseases. These results on the latter are consistent obtained on Sebastiania chamaelea (L.) [18] and on Emilia sonchifolia (L.) [19] which detected in addition to these metabolites, the presence of saponosides. These compounds are frequently encountered in plant extracts such as Ziziphus mauritiana Lam [20].

\subsection{Total Phenolic Content}

Total phenolics constitute one of the major groups of compounds acting as primary antioxidants, it was reasonable to determine their total amount in leaves and bark extracts [11]. The content of phenolic compounds (mg GAE/g DM) in all extracts, determined from regression equation of calibration curve $(y=3.120 x$ $+0.069, \mathrm{R}^{2}=0.98$ ) and expressed in gallic acid equivalents (GAE). The results show that the total phenolic contents vary significantly between the extracts of the plant parts studied but also the extraction solvents (Table 1). The maximum content is obtained on the hydro-acetonic extract of the bark with a value of $64.72 \pm 1.02 \mathrm{mg} \mathrm{GAE} / \mathrm{g}$ dry matter $(\mathrm{DM})$ followed by a value of $56.58 \pm 0.81 \mathrm{mg}$ 
Table 1. Total Phenolic (TP) content (mg GAE/g DM) of the various extracts of $S$. birrea.

\begin{tabular}{ccccccc}
\hline \multirow{2}{*}{ Extracts } & \multicolumn{2}{c}{ Infuse } & \multicolumn{2}{c}{ Hydro-acetonic } & \multicolumn{2}{c}{ Hydromethanolic } \\
\cline { 2 - 7 } & Leaves & Bark & Leaves & Bark & Leaves & Bark \\
\hline Total phenolic & $6.39 \pm 0.03^{\mathrm{a}}$ & $37.48 \pm 1.33^{\mathrm{b}}$ & $52.70 \pm 0.55^{\mathrm{c}}$ & $64.72 \pm 1.02^{\mathrm{d}}$ & $56.58 \pm 0.81^{\mathrm{e}}$ & $34.95 \pm 0.29^{\mathrm{f}}$ \\
\hline
\end{tabular}

GAE/g of DM obtained on the methanolic extract of the leaves. On the other hand the infused extract of the leaves has the lowest phenol content with a value of $6.39 \pm 0.03 \mathrm{mg} \mathrm{GAE} / \mathrm{g}$ of DM. This disparity of polyphenols in different organs of the same plant is a phenomenon reported by several authors, on several Saharan medicinal plants such as Anvillea radiata Coss. \& Dur and Rumex vesicarius $L$. [21].

\subsection{Antioxidant Activity}

The results of the DPPH and ABTS radical tests were obtained by following the evolution of the percentage inhibition as a function of the variation in the concentration of the extracts.

\subsubsection{DPPH Radical Scavenging Assay}

The inhibition percentages show that at all the concentrations tested, our extracts significantly inhibit the DPPH radical as in the case of hydro-ethanolic extracts from the leaves and bark of Piliostigma thonningii Schumach [16]. In all the extracts tested, the barks exhibit greater activity than that of the leaves. Indeed, the greatest activity obtained at the concentration of $2.5 \mathrm{mg} / \mathrm{mL}$, the bark has a percentage inhibition of $91.04 \% \pm 0.001 \%$ compared to the leaves, the most important of which is $99.80 \% \pm 0.021 \%$. As for the ascorbic acid used as a reference has a PI with the DPPH radical of $94.86 \% \pm 0.008 \%$ at $1.25 \mathrm{mg} / \mathrm{mL}$ then its activity evolved to a plateau up to $2.5 \mathrm{mg} / \mathrm{mL}$ (Figure 1). The percentages of inhibition obtained on the latter are greater than those of the acetone extract $(71.76 \%$ at $0.825 \mathrm{mg} / \mathrm{mL})$ on Foeniculum vulgare [22]. Thus, in order to better compare the anti-free radical activity of the various plant extracts, the $\mathrm{IC}_{50}$ were determined. The extracts of the leaves (hydromethanolic and infused) have higher $\mathrm{IC}_{50}$ than those of the bark with respective values of $0.480 \pm 0.00014$ $\mathrm{mg} / \mathrm{mL}$ and $0.894 \pm 00008 \mathrm{mg} / \mathrm{mL}$ against $0.156 \pm 0.0007 \mathrm{mg} / \mathrm{mL}$ and 0.407 $\pm 0.0001 \mathrm{mg} / \mathrm{mL}$. However, the hydro-acetone extract of the bark has an $\mathrm{IC}_{50}$ greater than that of the leaves with respective values of $0.361 \pm 0.000028 \mathrm{mg} / \mathrm{mL}$ against $0.301 \pm 0.00006 \mathrm{mg} / \mathrm{mL}$. At the same time, ascorbic acid (vitamin C) exhibits an $\mathrm{IC}_{50}$ of $0.051 \pm 0.0000 \mathrm{mg} / \mathrm{mL}$.

\subsubsection{ABTS Radical Cation Decolourisation Assay}

From Figure 2, it can be seen that whatever the extraction solvent, the extracts from the leaves and bark significantly inhibited the ABTS cation radical. As in the case of the DPPH test, in all the extracts tested, the barks exhibit greater activity than that of the leaves. Indeed, the bark extract reached its maximum activity at $1.25 \mathrm{mg} / \mathrm{mL}$ with a PI of $99.80 \% \pm 0.003 \%$ compared to the extract of the 


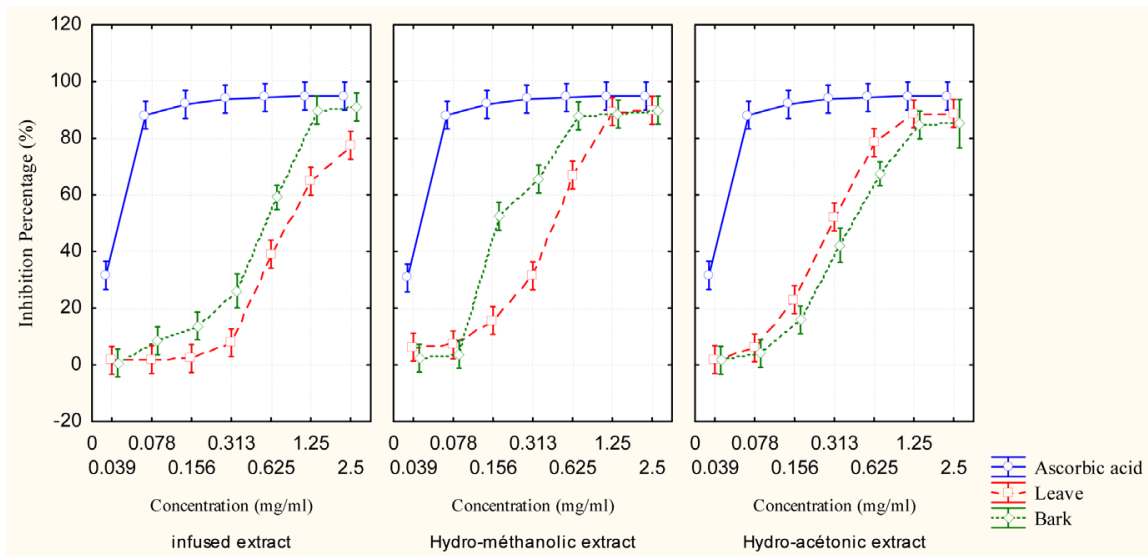

Figure 1. Inhibition percentage evolution on DPPH radical in leaves and bark extracts and ascorbic acid.
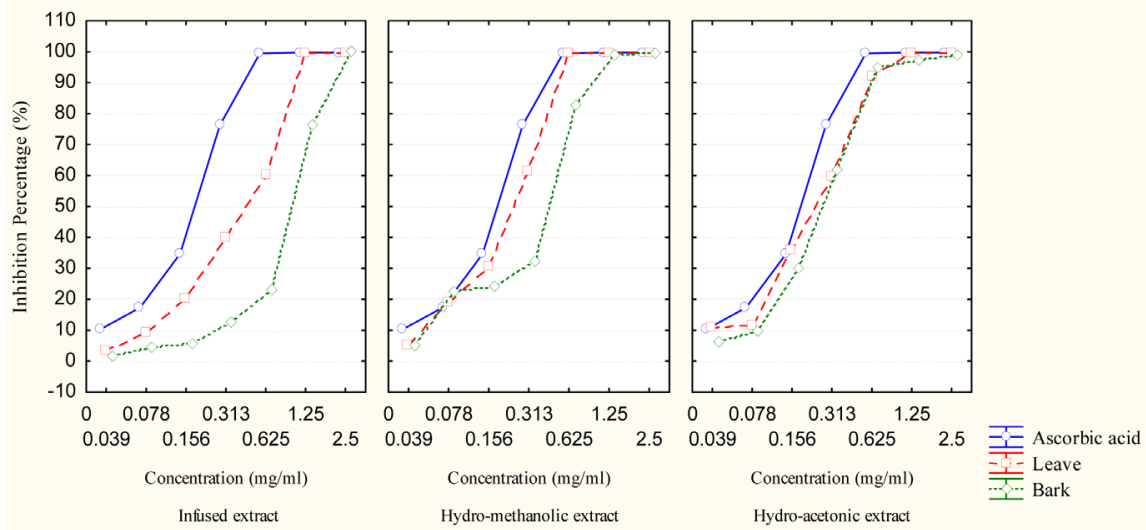

Figure 2. Inhibition percentage evolution on ABTS radical in leaves and bark extracts and ascorbic acid.

leaves which has a greater PI of $99.75 \pm 0.003$ at $2.5 \mathrm{mg} / \mathrm{mL}$. At the weakest concentrate tested $(0.039 \mathrm{mg} / \mathrm{mL})$, the extracts inhibited $10.63 \% \pm 0.007 \%$ the ABTS cation radical and $6.25 \% \pm 0.003 \%$ the DPPH radical against ascorbic acid which inhibits $10.25 \% \pm 0.002 \%$ the ABTS cation radical and $31.59 \% \pm 0.012 \%$ the DPPH cation radical. At the highest concentration tested $(2.5 \mathrm{mg} / \mathrm{mL})$ and whatever the extraction solvent, the bark extract has the greatest PI with $91.04 \% \pm$ $0.001 \%$ on the DPPH radical and $99.80 \% \pm 0.021 \%$ on the radical ABTS against ascorbic acid $94.86 \% \pm 0.008 \%$ on the DPPH radical and $99.80 \% \pm 0.021 \%$ on the ABTS cation radical. By comparing the two methods, the PI shows that the bark extracts are more active than the leaf extract. However, ascorbic acid inhibits the ABTS radical $(99.81 \% \pm 0.014 \%)$ more than the DPPH radical $(94.86 \% \pm$ $0.008 \%)$. These results agree with those found on hydro-ethanolic extracts from the leaves and bark of Piliostigma thonningii Schumach [16].

\subsubsection{FRAP Test}

In analogy with the inhibitory power, the evolution of the reducing power as a function of the concentration of the extracts (Figure 3) shows a strong activity 


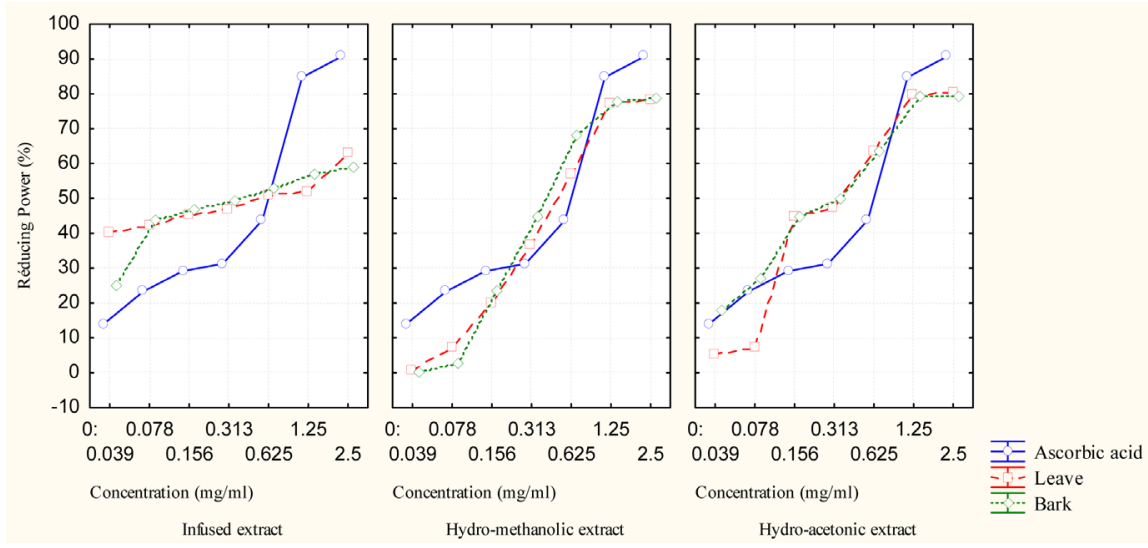

Figure 3. Reducing power evolution in leaves and bark extracts and ascorbic acid.

of the plant. At all tested concentrations the extracts significantly reduce ferric ion. The aqueous, hydro-acetonic and hydro-methanolic extracts at the maximum concentration tested $(2.5 \mathrm{mg} / \mathrm{mL})$ gave reducing powers (RP) of the leaves and bark respectively of $62.83 \% \pm 0.003 \%, 58.96 \% \pm 0.002 \%, 80.33 \% \pm 0.001 \%$ $79.29 \% \pm 0.004 \%$ and $78.29 \% \pm 0.003 \%$ against $78.59 \% \pm 0.002 \%$. At the same concentration as the extracts, ascorbic acid has a strong reducing power on ferric ion with a RP of $90.45 \% \pm 0.406 \%$.

The results of the antioxidant activity of Sclerocarya birrea extracts on all three tests carried out show that the hydro-alcoholic extracts of the bark are more active. In fact, at the same concentrations tested, they exhibit lower $\mathrm{IC}_{50}$. Furthermore, at the same concentrations tested, the $\mathrm{IC}_{50}$ obtained by the DPPH test are lower than those of the ABTS method. This could be explained by the presence of active substances which exhibit absorption bands at the same wavelength as the DPPH radical, thus leading to an increase in absorbance [6]. The FRAP test shows a better reducing power of the ferric ion of the bark compared to the leaves. Thus, by these 3 tests, we see that the antioxidant activity of the bark is stronger than that of the leaves. This could be explained by the polyphenol content of the bark which is about twice as high compared to the leaves.

\section{Conclusion}

This study has demonstrated the antioxidant activity of aqueous and hydro-alcoholic extracts of Sclerocarya birrea by different methods. It shows that the hydro-alcoholic extracts of the bark have a strong antioxidant activity compared to the leaves. These results could constitute a solid scientific basis to investigate new natural molecular compounds, complementary to the existing chemical therapy. In fact, following the simultaneous presence of secondary metabolites and mineral salts, the evaluation of antioxidant activity made it possible to partially support their effect on hyperglycemia. In view of this work, biological tests with hydromethanolic and hydro-acetonic extracts should provide further evidence of the hypoglycemic activity of Sclerocarya birrea. A subsequent study with the aim of characterizing phenolic compounds, isolating, and identifying molecules with 
antioxidant activity must be achieved.

\section{Conflicts of Interest}

The authors declare that they have no known competing financial interests or personal relationships that could have appeared to influence the work reported in this paper.

\section{References}

[1] Sarr, S.O., Fall, A.D., Gueye, R., Diop, A., Diatta, K., Diop, N., Ndiaye, B. and Diop, Y.M. (2015) Etude de l'activité antioxydante des extraits des feuilles de Vitex doniana (Verbenacea). International Journal of Biological and Chemical Sciences, 9, 1263-1269. https://doi.org/10.4314/ijbcs.v9i3.11

[2] Dias, J.S. (2019) Nutritional Quality and Effect on Disease Prevention of Vegetables. Food and Nutrition Sciences, 10, 369-402. https://doi.org/10.4236/fns.2019.104029

[3] Dias, J.S. and Ryder, E.J. (2011) World Vegetable Industry: Production, Breeding, Trends. In: Janick, J., Ed., Horticultural Review, Vol. 38, Timber Press, Portland, 299-357. https://doi.org/10.1002/9780470872376.ch8

[4] Antiochia, R., Gatta, T., Mazzone, E., Mannina, L. and Campanella, L. (2011) A Comparison among Three Different Analytical Methods to Test the Scavenging Properties of Different Integrators against Radicalic Stress. Pakistan Journal of Pharmaceutical Sciences, 27, 25-32.

[5] Gaye, A.A., Cissé, O.I., Ndiaye, B., Ayessou, N.C., Cissé, M. and Diop, C.M. (2019) Evaluation of Phenolic Content and Antioxidant Activity of Aqueous Extracts of Three Carica papaya Varieties Cultivated in Senegal. Food and Nutrition Sciences, 10, 276-289. https://doi.org/10.4236/fns.2019.103021

[6] Fall, A.D., Sy, A.N., Fokou, J.B.H., Fomi, J.O.N., Dieng, M., Dieng, S.I.M. and Bassene, E. (2015) Phytochemical Screening, Polyphenol Content and Antioxidant Studies of Ethanol Leaf Extract of Combretum aculeatum Vent. European Journal of Medicinal Plants, 10, 1-7. https://doi.org/10.9734/EJMP/2015/20294

[7] Diallo, F.A., Sandwidi, A., Dao, M.E.C., Bationo-Kando, P. and Diallo, B.O. (2020) Caractérisation phénotypique des plantules de quatre populations de Sclerocarya birrea (A. Rich.) Hochst. au Burkina Faso. Bois Et Forets Des Tropiques, 344, 33-46. https://doi.org/10.19182/bft2020.344.a31898

[8] Agbogan, A., Tozo, K., Wala, K., Bellefontaine, R., Dourma, M., Akpavi, S., Woegan, Y.A., Dimobe, K. and Akpagana, K. (2015) Structure des populations de Sclerocarya birrea, Lannea microcarpa et Haematostaphis barteri au nord du Togo. Journal of Animal \&Plant Sciences, 25, 3871-3886.

[9] Sene, A.L., Niang, K., Faye, G., Ayessou, N., Sagna, M.B., Cisse, M., Diallo, A., Cisse, O.K., Gueye, M. and Guisse, A. (2018) Identification des usages de Sclerocarya birrea (A. rich) Hoscht Dans la Zone Du Ferlo (Senegal) et evaluation du potentiel biochimique et nutritionnel de son fruit. African Journal of Food, Agriculture, $\mathrm{Nu}$ trition and Development, 18, 13470-13489. https://doi.org/10.18697/ajfand.82.17015

[10] Karumi, Y., Onyeyili, P.A. and Ogugbuaja, V.O. (2004) Identification of Active Principles of M. balsamina (Balsam Apple) Leaf Extract. Journal of Medical Sciences, 4, 179-182. https://doi.org/10.3923/jms.2004.179.182

[11] Miliauskas, G., Venskutonis, P.R. and Van Beek, T.A. (2004) Screening of Radical Scavenging Activity of Some Medicinal and Aromatic Plant Extracts. Food Chemi- 
stry, 85, 231-237. https://doi.org/10.1016/j.foodchem.2003.05.007

[12] World Health Organization (2013) WHO Traditional Medicine Strategy: 20142023. World Health Organization, Geneva, 1-4. http://apps.who.int/iris/handle/10665/92455

[13] Georgé, S., Brat, P., Alter, P. and Amiot, M.J. (2005) Rapid Determination of Polyphenols and Vitamin C in Plant-Derived Products. Journal of Agricultural and Food Chemistry, 53, 1370-1373. https://doi.org/10.1021/jf048396b

[14] Teodoro. De Oliveira, R., Marques Junior, J., Nascimento, D.V.D. and Stefani, R. (2014) Phytochemical Screening and Comparison of DPPH Radical Scavenging from Different Samples of Coffee and Yerba Mate Beverages. International Journal of Scientific and Research Publications, 4, 1-7.

[15] Saeed, N., Khan, M.R. and Shabbir, M. (2012) Antioxidant Activity, Total Phenolic and Total Flavonoid Contents of Whole Plant Extracts Torilis leptophylla L. BMC Complementary and Alternative Medicine, 12, Article No. 221. https://doi.org/10.1186/1472-6882-12-221

[16] Dieng, S.I.M., Fall, A.D., Diatta-Badji, K., Sarr, A., Sene, M., Mbaye, A., Diatta, W. and Bassene, E. (2017) Evaluation de l'activité antioxydante des extraits hydroethanoliques des feuilles et écorces de Piliostigma thonningii Schumach. International Journal of Biological and Chemical Sciences, 11, 768-776. https://doi.org/10.4314/ijbcs.v11i2.19

[17] Rasyid, Z.A., Farida A., Daud, S.H., Wiwin, S., Wijaya, K.I. and Tangke, A.E. (2020) Bioactivities of Forest Medicinal Plants on Kutai Ethnic (Indonesia) of Tapak Leman (Hippobroma longiflora (L) G. Don). GSC Biological and Pharmaceutical Sciences, 11, 91-98. https://doi.org/10.30574/gscbps.2020.11.2.0125

[18] Mamadou, R.S., Moussa, I., Sessou, P., Yehouenou, B., Agbangnan, P.D.C., Illagouma, A.T., Abdoulaye, A., Sohounhloué, D.C.K. and Ikhiri, K. (2014) Etude phytochimique, activités antiradicalaire, antibactérienne et antifongique d'extraits de Sebastiania chamaelea (L.) Müll. Journal de la Société Ouest-Africaine de Chimie, 37, 10-17.

[19] Essien, G.E., Sunday, T.P. and Udoette, I.M. (2020) In Vitro Antioxidant Analysis and Quantitative Determination of Phenolic and Flavonoid Contents of Emilia sonchifolia (L) D.C (Asteraceae) Leaf Extract and Fractions. GSC Biological and Pharmaceutical Sciences, 11, 44-52. https://doi.org/10.30574/gscbps.2020.11.2.0123

[20] Folié, N.B.Y., Kouakou, L.P.M.S., Coulibaly, K., Sanogo, R. and Koné-Bamba, D. (2017) Composition en sels minéraux et en métabolites secondaires de Ziziphus mauritiana Lam., une plante antihyperglycémiante. J. la Société Ouest-Africaine Chim, 44, 30-35.

[21] Beddou, F. (2015) Etude phytochimique et activités biologiques de deux plantes médicinales sahariennes Rumex vesicarius L. et Anvillea radiata Coss. \& Dur. Thèse de doctorat, Biologie Cellulaire et Biochimie, Université Abou Bekr Bailked, Tlemcen, Algérie.

[22] Saheb, R. and Fethoun, M. (2015) Evaluation de l'activité antioxydant de différents extraits de Foeniculum vulgare. Mémoire de Master, biologie, Université A. MIRABéjaïa, Algérie, 62. 